\section{REFERENCES}

Blaxton, T. A. (1989). Investigating dissociations among memory measures: Support for a transfer appropriate processing framework. Journal of Experimental Psychology: Learning, Memory, \& Cognition, 15, 657-668.

Forster, K., BoOKer, J., Schacter, D. L., \& DAvis, C. (1990). Masked repetition priming: Lexical activation or novel memory trace? Bulletin of the Psychonomic Society, 28, 341-345.

Graf, P., SChacter, D. L. (1985). Implicit and explicit memory for new associations in normal and amnesic subjects. Journal of Experimental Psychology: Learning, Memory, \& Cognition, 11, 501-518.

Richardon-KLavehn, A., \& Bjork, R. A. (1988). Measures of memory. Annual Review of Psychology, 39, 475-543.

RoEDIGER, H. L., III (1990a). Implicit memory: A commentary. Bulletin of the Psychonomic Society, 28, 373-380.

ROEDIGER, H. L. (1990b). Implicit memory: Retention without remembering. American Psychologist, 45, 1043-1056.

Roediger, H. L., Srinivas, K., \& Weldon, M. S. (1989). Dissociations between implicit measures of retention. In $\mathbf{S}$. Lewandowsky, J. C. Dunn, \& K. Kirsner (Eds.), Implicit memory: Theoretical issues (pp. 67-84). Hillsdale, NJ: Erlbaum.

SCHACTER, D. L. (1987). Implicit memory: History and current status. Journal of Experimental Psychology: Learning, Memory, \& Cognition, 13, 501-518.
SCHACTER, D. L. (1989). On the relation between memory and consciousness: Dissociable interactions and conscious experience. In $\mathrm{H}$. L. Roediger \& F. I. M. Craik (Eds.), Varieties of memory and consciousness: Essays in honor of Endel Tulving (pp. 355-389). Hillsdale, NJ: Erlbaum.

SCHACTER, D. L. (1991). Perceptual representation systems and implicit memory: Toward a resolution of the multiple system debate. In A. Diamond (Ed.), The development and neural basis of higher cognitive function. New York: New York Academy of Sciences Press.

SQUIRE, L. R. (1986). Mechanisms of memory. Science, 232, 1612-1619.

SQUIRE, L. R. (1987). Memory and brain. New York: Oxford University Press.

Tulving, E. (1983). Elements of episodic memory. Oxford: Oxford University Press.

Tulving, E. (1985). How many memory systems are there? American Psychologist, 40, 385-398.

Tulving, E., Schacter, D. L., \& Stark, H. D. (1982). Priming effects in word-fragment completion are independent of recognition memory. Journal of Experimental Psychology: Learning, Memory, \& Cognition, 8, 336-342.

(Manuscript received November 30, 1991.)

\title{
Call for Assistance in The Compilation of a History of the Psychonomic Society
}

The Governing Board of the Psychonomic Society is pleased to announce that Robert C. Bolles has agreed to serve as the first Historian of the Society.

All members who might have information relevant to this undertaking are invited to send it directly to Dr. Bolles. Founding members and those who attended the early meetings are especially encouraged to record their reminiscences. While Dr. Bolles hopes to collect as much information as possible relevant to the history of the Society, he will concentrate first on the early history.

Dr. Bolles's address is Department of Psychology, University of Washington, Seattle, Washington 98195 (phone: 206-543-2631). 